\title{
Empati Anak Usia Dini: Pengaruh Penggunaan Video Animasi dan Big Book di Taman Kanak- Kanak
}

\author{
Jojor Renta Maranatha ${ }^{1 凶}$, Dewi Indriati Hadi Putri ${ }^{2}$ \\ Pendidikan Guru Pendidikan Anak Usia Dini, Universitas Pendidikan \\ Indonesia, Indonesia ${ }^{1}$ \\ Pendidikan Sistem Telekomunikasi, Universitas Pendidikan Indonesia, \\ Indonesia ${ }^{2}$
}

DOI: $10.31004 /$ obsesi.v6i3.1881

\begin{abstract}
Abstrak
Tujuan penelitian ini untuk dapat mengetahui pengaruh media pembelajaran terhadap empati anak usia dini. Metode penelitian menggunakan metode kuasi ekperimen, dengan desain penelitian pretest-posttest control group design. Penelitian ini dilaksanakan di Purwakarta, Indonesia. Partisipan dalam penelitian ini anak rentang usia 5-6 tahun yang berjumlah 38 . Adapun pengumpulan data yang dilakukan dengan rating scale empati anak usia dini. Kemudian data ini dianalisis dengan menggunakan paired sample t-test untuk mengetahui pengaruh metode pembelajaran terhadap empati anak usia dini, dan independent sample t-test untuk mengetahui perbedaan empati antara grup ekperimen dan grup kontrol. Hasil dari penelitian ini ialah: (1) Terdapat pengaruh media pembelajaran video animasi empati terhadap empati anak usia dini. (2) Terdapat perbedaan empati anak usia dini yang mendapatkan pembelajaran dengan media video animasi empati dengan anak usia dini yang mendapatkan pembelajaran dengan media big book Empati. Kesimpulan yang diperoleh bahwa media video animasi lebih efektif daripada media big book dalam mengingkatkan empati anak usia dini.
\end{abstract}

Kata kunci: empati; video animasi; big book

\section{Abstract}

This paper aims to know the effects of the instructional media toward early childhood empathy. This paper adopts a quasi-experiment research with with a pretest-posttest control group design, and conduct in Purwakarta, Indonesia. The research participants were 38 children with an age range of 5-6years old. Data collection in this study was carried out with a rating scale of early childhood empathy. Data were analyzed with the paired sample t-test to find out whether the instructional media had any influence on early childhood empathy, and independent sample t-test to find the difference of early childhood empathy in the experimental and control groups. The results of this study are (1) There is an effect of instructional media toward early childhood empathy. (2). There are differences in the early childhood empathy who gets animation video as an instructional media with those who gets big book media. In conclusion, animation video as an instructional media is more effective than big book as an interactional media in early childhood empathy.

Keywords: empathy; animation video; big book

Copyright (c) 2021 Jojor Renta Maranatha, Dewi Indriati Hadi Putri

$\triangle$ Corresponding author :

Email Address : jojor.renta@upi.edu (Bandung, Indonesia)

Received 26 May 2021, Accepted 16 November 2021, Published 24 November 2021

Jurnal Obsesi : Jurnal Pendidikan Anak Usia Dini, 6(3), 2022 | 1991 


\section{PENDAHULUAN}

Pendidikan anak usia dini memiliki peranan penting untuk membantu dalam mengoptimalkan aspek-aspek perkembangan anak usia dini, salah satunya adalah aspek perkembangan sosial emosional. Empati merupakan salah satu aspek dasar dari kemampuan sosial. Empati disefinisikan sebagai usaha individu untuk mengerti emosi dan perasaan orang lain (Gehlbach, 2004) (M. L. Hoffman, 2019), memungkin individu untuk membangun persepsi mengenai orang lain melalui imaginasi, imitasi, observasi, penggunaan bahasa, dan kemampuan kognitif (Mcdonald \& Messinger, 2013). Dasar untuk hubungan baik dan positif dengan orang lain dapat melalui kemampuan memahami pikiran dan perasaan orang lain (Batson, 2013).

Empati sudah ada dari masa bayi, walaupun dalam bentuk sederhana seperti bayi tertawa saat melihat orang tertawa. Perkembangan empati, dari rangsangan ke internalisasi, adalah proses kompleks yang dimulai pada awal masa bayi (Dvash \& Shamay-Tsoory, 2014). Semakin bertambah usia, maka kemampuan individu untuk berempati makin baik, dengan ditandai semakin meningatnya kemampuan untuk menyadari dan memahami perasaan orang lain (Martin L. Hoffman, 2000). Empati dapat melibatkan aspek kognitif dan afektif (Van Lange, 2008) (Decety \& Jackson, 2004). Pada anak usia dini perkembangan kognitif masih pada fase berfikir kongkrit, dan menuju abstrak pada akhir masa usia dini. Sehingga anak tidak sepenuhnya mengembangkan empati berdasarkan perspektif mereka sampai mereka memiliki kemampuan berpikir abstrak atau sekitar usia 12 tahun (Dvash \& Shamay-Tsoory, 2014).

Anak yang memiliki empati yang baik, juga memiliki kecerdasan interpersonal yang baik pula, karena empati sangat berkaitan dengan kecerdasan interpesenal anak dan menjadi dasar dalam berinteraksi sehari-hari. Disisi lain, empati juga menjadi dasar dalam pengembangan moral anak dan memotivasi perilaku prososial (Decety \& Cowell, 2014). Menanamkan empati pada anak perlu dilakukan sejak kecil karena manusia adalah makhluk sosial selalu berhubungan, berinteraksi antara individu dengan individu lainnya, sehingga memerlukan sikap saling memahami. Interkasi sosial yang positif secara umum dipengaruhi oleh pemahaman individu terhadap orang lain. Empati memungkinkan individu untuk memahami perasaan dan pikiran orang lain. Hasil penelitian yang dilakukan oleh Findlay menunjukkan bahwa anak usia dini dengan empati yang tinggi akan memiliki sikap prososial yang tinggi dan lebih peka terhadap sikap yang ditunjukan oleh orang lain bila dibandingkan dengan anak yang memiliki empati yang rendah (Findlay et al., 2006). Namun, kenyataannya menunjukkan bahwa banyak anak yang masih kurang memiliki rasa empati. Hal ini didapat melalui wawancara dan observasi awal yang dilakukan oleh peneliti pada Taman Kanakkanak di Purwakarta didapati bahwa sebagian anak belum mempunyai kemmapuan untuk berempati terhadap orang lain, seperti: menertawakan teman yang keliru menjawab pertanyaan guru, meledek teman yang masih malu bila diminta untuk bernyanyi, marah ketika ada yang mendapatkan pujian dari guru, dan lain sebagainya.

Empati memiliki beberapa aspek yang dapat memperlihatkan bahwa seseorang memiliki empati yang tinggi atau kurang, adapun aspek empati menurut Davis terdiri dari Perspective taking yang artinya kemampuan untuk memahami sudut pandang orang lain; Fantasi adalah perubahan imajinasi individu kedalam pikiran, perasaan dan tindakan; Empathy concern adalah perasaan simpati yang ditujukan kepada orang lain ketika mengalami kesulitan; Personal distress adalah perasaan yang terjadi pada diri sendiri seperti adanya rasa gelisah yang ketika akan menghadapi sesuatu (Mark H. Davis, 1983). Empati yang dimiliki oleh anak memiliki manfaat, antara lain empati memotivasi perilaku membantu, memfasilitasi ikatan sosial dengan orang lain, dan meningkatkan dukungan sosial anak. Sehingga empati harus di stimulus secara maksimal, agar berkembang dengan baik. Perkembangan empati yang tidak sesuai dengan usia, dapat menimbulkan efek negatif dikehidupan individu tersebut. Berbagai cara dapat dilakukan oleh guru dalam memperkenalkan anak usia dini bagaimana berperilaku empati kepada orang lain. Dalam pembelajaran guru dapat menggunakan berbagai macam media untuk mengajarkan aspek sosial kepada anak usia dini, termasuk empati. Media pembelajaran tersebut dapat berupa media digital seperti video atau 
media konvensional seperti buku. Video dan buku yang digunakan dalam pembelajaran memiliki berbagai macam jenis, seperti video animasi dan big book.

Hasil Penelitian Vanchon (2013), menunjukan bahwa perkembangan empati anak yang tidak optimal dapat meningkatkan perilaku agresif (Vachon et al., 2014). Selain penelitian tersebut, hasil penelitian Findlay mengemukakan bahwa tingat agresifitas anak yang mempunyai empati tinggi jauh lebih rendah bila dibandingkan dengan anak yang memiliki empati rendah (Findlay et al., 2006). Penelitian lain yang dilakukan oleh Mardliyah. dkk (2021), mengungkapkan bahwa interkonektivitas sekolah, orang tua, dan anak didik tiga berdampak positif terhadap tumbuhnya empati pada anak usia dini (Mardliyah et al., 2020). Kebaruan penelitian ini terletak pada metode yang digunakan. Penelitian terdahulu metode yang digunakan adalah kualitatif etnografis yang bertujuan untuk menginvestigasi kejadian atau tindakan pada orang atau masyarakat. Pada penelitian ini, metode yang digunakan adalah eksperimen yang bertujuan untuk mengetahui perbedaan empati anak usia din. dan untuk mengetahui seberapa besar pengaruh penggunaan video animasi dan big book terhadap empati.

Video animasi mempunyai karakterisitik berupa gambar animasi yang dilengkapi dengan suara dan lagu, serta alur cerita yang diperankan oleh tokoh yang memerankan cerita pada video tersebut. Karakteristik tersebut dapat menarik perhatian anak usia dini untuk menonton video tersebut dengan seksama. Menonton video animasi yang berisi mengenai contoh bagaimana berempati dalam kehidupan sehari-hari dapat menstimulus anak untuk menerapkan kegiatan-kegiatan yang berkaitan dengan empati di kehidupan sehari-harinya. Penggunaan video animasi sebagai media pembelajaran untuk meningkatkan empati anak usia dini dapat dilakukan dengan cara menayangkan video mengenai berbagai macam respon individu terhadap perasaan dan pikiran orang lain. Melalui video animasi, anak dapat mengetahui perilaku empati terhadap perasaan dan pikiran orang lain. Sehingga diharapkan dengan mengetahui sikap yang harus ditunjukan oleh anak terhadap perasaan dan pikiran orang lain, dapat meningkatkan perilaku empati anak usia dini.

Berbeda dengan video animasi, big book adalah buku berukuran besar, berisikan gambar dan teks yang disertai dengan alur cerita dan tokoh pada cerita tersebut. Bercerita dengan media big book memungkinkan guru untuk berinteraksi dengan anak secara baik, karena ukuran buku yang besar dan juga memilik gambar serta ilustrsi mengenai cerita sehingga menarik perhatian anak. Selain itu, ukuran big book yang besar juga memungkinkan seluruh anak di dalam kelas untuk melihat buku secara jelas dan lebih memahami isi dari cerita yang ada di big book tersebut. Pebriana (2017) mengemukakan hasil penelitiannya bahwa melalui mendongeng maka secara otomatis akan terjadi transformasi nilai melalui tingkah laku dan karakter tokoh yang ada dalam cerita (Hana Pebriana, 2017). Pada penelitian ini, mendongeng dilakukan dengan bantuan big book yang berisi cerita mengenai contohcontoh empati untuk anak usia dini. Selain itu, berbeda dengan penelitian yang dilakukan oleh Purnamasari. dkk, (2020) yang menunjukan bahwa big book lebih efektif dalam meningkatkan toleransi anak 5-6 tahun bila dibandingan dengan buku bekururan lebih kecil (Mega Purnamasari et al., 2019) . Big book yang digunakan dalam penelitian ini bertujuan untuk meningkatkan empati anak usia dini.

Berdasarkan kajian tentang empati yang telah dipaparkan, maka tujuan dari penelitian ini adalah untuk mengetahui pengaruh penggunaan video animasi serta big book sebagai media pembelajaran terhadap empati anak usia dini. Selain itu, untuk mengetahui perbedaan empati anak usia dini yang mendapatkan pembelajaran dengan menggunakan media video animasi dengan anak usia dini yang mendapatkan pembelajaran dengan media big book. Penelitian ini berkontribusi untuk memberikan pengetahuan mengenai alternatif penggunaan media pembelajaran untuk menstimulus aspek sosial emosional anak usia dini, khususnya empati. 


\section{METODOLOGI}

Pada penelitian ini menggunakan penelitian kuasi eksperimen, dengan desain penelitian pretest-posttes control group design. Terdapat dua grup pada penelitian ini, yaitu grup eksperimen dengan menggunakan media video animasi dan grup kontrol dengan menggunakan media big book. Terdapat beberapa tahapan dalam penelitian ini, yaitu: 1) Merumuskan instrumen penelitian; 2) Melaksanakan uji coba instrumen penelitian; 3) Menghitung reabilitas dan validitas instrumen penelititian; 4) Melakukan pretest pada kelompok eksperimen dan kelompok kontrol; 5) Memberikan intervensi pada kelompok eksperimen dan kelompok kontrol; 6) Melakukan posttest pada kelompok eksperimen dan kelompok kontrol; 7) Mengolah data penelitian. Alur penelitian digambarkan pada gambar 1 di bawah ini.

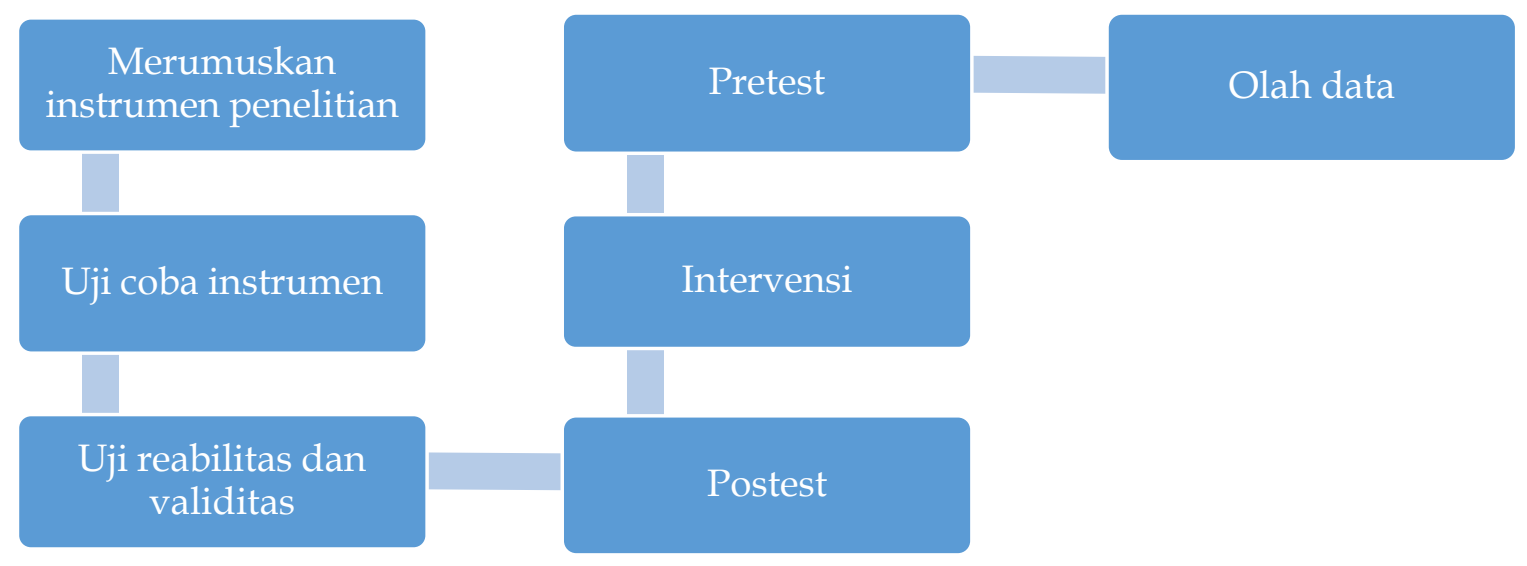

Gambar 1. Alur Penelitian

Partisipan yang terlibat pada penelitian ini adalah anak Taman Kanak-kanak salah satu TK di Purwakarta anak dengan rentang usia 5-6 tahun yang berjumlah 38 anak di kelas B, yaitu kelas B1 sebagai kelas eksperimen dan kelas B2 sebagai kelas kontrol. Perlakuan pada grup eksperimen dan kontrol dilakukan sebanyak tiga kali.

Rating scale empati anak usia dini digunakan sebagai instrumen pengumpulan data pada penelitian ini. Rating scale dikembangkan berdasarkan aspek empati yang dikemukan oleh Williams dkk, (2005) diantaranya responsive joy ialah perasaan gembira karena orang lain bahagia, emphatic concern ialah perasaan sedih/duka karena orang lain kurang beruntung serta mengalami satu masalah, dan responsive distress ialah perasaan terganggu sekaligus tidak nyaman karena orang lain sedang mengalami masalah, kemudian cenderung diekspresikan dengan tindakan positif (Williams et al., 2005). Rating scale tersebut digunakan dalam pretestposttes pada kelas ekperimen dan kelas kontrol. Sebelum instrumen digunakan untuk mengambil data dalam penilitian ini, dilakukan uji coba instrumen terlebih dahulu untuk mendapatkan isntrumen yang valid dan reliabel.

Uji paired sample t test digunakan menganalisis data untuk mengetahui apakah terdapat pengaruh penggunaan media pembelajaran terhadap empati anak usia dini serta independent sample $t$ test untuk mengetahui perbedaan empati anak usia dini antara grup eksperimen dan grup kontrol. Sebelum analisis data dilakukan, melakukan uji normalitas terlebih dahulu dengan uji Kolmogorov Smirnov serta uji homogenitas dengan uji Levene.

\section{HASIL DAN PEMBAHASAN}

Data pada penelitian ini terdiri dari data variabel terikat yaitu empati anak usia dini dan video animasi serta big book sebagai variabel bebas. Data variabel bebas dan variabel terikat diperoleh melalui pretest dan posttest. Analisis kuantitatif dilakukan bertujuan untuk mengetahui apakah terdapat pengaruh media pembelajaran terhadap empati anak usia dini, 
Empati Anak Usia Dini: Pengaruh Penggunaan Video Animasi dan Big Book di Taman Kanak-Kanak DOI: $10.31004 /$ obsesi.v6i3.1881

yaitu dengan membandingkan kedua data penelitian pretest dan postest kelas eksperimen serta pretest dan posttest kelas kontrol. Sebelum uji perbandingan, dilakukan uji normalitas data terlebih dahulu sebagai syarat uji perbandingan.

Tabel 2. Hasil Pengujian Normalitas Data Pretest dan Postest Group Eksperiment serta Pretest dan Postest Group Control Kolmogorov-Smirnova

\begin{tabular}{ccc}
\hline & $\begin{array}{c}\text { Shapiro-Wilk } \\
\text { Sig. }\end{array}$ & Keterangan \\
\hline Pretest Eksperiment &, 880 & Sig $>0,05$ (data berdistribusi normal) \\
Posttest Eksperiment &, 713 & Sig $>0,05$ (data berdistribusi normal) \\
Pretest Control &, 010 & Sig $>0,05$ (data berdistribusi normal) \\
Posttest Control &, 000 & Sig $<0,05$ (data tidak berdistribusi \\
& & normal) \\
\hline
\end{tabular}

Normalitas data dapat dilihat dari Shapiro-Wilk Sig. yang merupakan nilai signifikansi data. Data yang memiliki nilai signifikansi $>0,05$, dinyatakan normal. Terlihat pada tabel tiga bahwa Sig. pretest eksperimen yaitu ,880; Sig. postest eksperimen yaitu ,713; Sig. pretest kontrol yaitu ,010; Sig Posttest kontrol yaitu ,000; yang artinya hanya tiga kelompok data yang berdistribusi norma sedangkan satu kelompok data yaitu data posttest group control tidak berdistribusi normal. Kemudian dilakukan uji Wilcoxon untuk mengetahui apakah terdapat pengaruh penggunaan media pembelajaran terhadap empati anak usia dini.

Tabel 3. Hasil Pengujian Wilcoxon Pretest dan Postest Group Ekspriment serta Pretest dan Postest Group Control

\begin{tabular}{lcc}
\hline & Asymp. Sig. (2-tailed) & Keterangan \\
\hline $\begin{array}{l}\text { Pretest Group } \\
\text { Eksperiment Postest Group }\end{array}$ &, 000 & Asymp. Sig. (2-tailed) $<0,000$ \\
$\begin{array}{l}\text { Essperiment } \\
\begin{array}{l}\text { Pretest Group Control } \\
\text { Postest Group Control }\end{array}\end{array}$ &, 000 & Asymp. Sig. $(2$-tailed $)<0,000$ \\
\hline
\end{tabular}

Tabel 3 memperlihatkan dari hasil perhitungan uji Wilcoxon, didapatkan hasil dengan nilai Asymp. Sig. (2-tailed) 0,000<0,05. Berdasarkan hasil tersebut, maka dapat diketahui bahwa $\mathrm{HO}$ ditolak dan $\mathrm{H}_{1}$ diterima. Sehingga menunjukkan terdapat pengaruh media pembelajaran yang dalam penelitian ini adalah video animasi dan big book terhadap empati anak usia dini.

Latif dkk (2016), menjelaskan bahwa pembelajaran merupakan proses yang dilakukan individu untuk memperoleh suatu perubahan perilaku yang baru secara keseluruhan, sebagai hasil dari pengalaman individu sendiri dalam interaksi dengan lingkungannya (Latif et al., 2016). Berdasarkan hal tersebut maka dapat katakan bahwa empati merupakan salah satu hasil proses pembelajaran. Perubahan tingkah laku dalam empati dapat terlihat dari anak yang sebelumnya belum memahami perasaan dan peduli terhadap orang lain, lalu menjadi memahami perasaan dan peduli terhadap orang lain.

Pembelajaran sangat erat kaitanya dengan media yang digunakan dalam proses pembelajaran. Media pembelajaran yang digunakan dalam penelitian ini adalah video animasi dan big book. Video animasi dapat menjadi media untuk menstimulus kemampuan kognitif anak usia dini, membantu memahami lingkungan dan kehidupan nyata, mengembangkan aspek sosial emosional, dan pembentukan nila dan perilaku. Aspek perkembangan emosi anak dapat distimulus melalui video animasi dengan menayangkan cerita mengenai keluarga, pertemanan, kejujuran, keberanian, percaya diri, dan kerja keras. Video animasi juga dapat memberikan contoh kepada anak mengenai berbagai macam norma dalam berperilaku yang dapat membanti anak untuk bekerja sama, berteman, dan 
mengontrol diri (Liu \& Luo, 2019). Mendengarkan cerita dapat membantu menumbuhkan empati serta pemahaman diri dan orang lain melalui identifikasi karakter tokoh pada cerita, memahami perbedaan saat teman menceritakan kembali, dan isi cerita yang dibacakan (Hibbin, 2016). Selain itu, mendengarkan cerita dengan big book dapat memberikan pengalaman kepada anak untuk mengetahui emosi yang belum mereka kenal sebelumnya, sehingga dapat memberikan pemahaman mengenai emosi dan empati yang sulit bila hanya dijelaskan saja. Sehingga media video animasi dan big book memberikan pengaruh terhadap empati anak usia dini. Hasil dari penelitian ini sejalan dengan penelitian yang dilaksanakan oleh Thompson. dkk (2019), yang menunjukan bahwa membaca nyaring efektif untuk meningkatkan empati anak (Thompson \& Melchior, 2019).

Penelitian kedua yang juga sesuai dengan hasil dari penelitian ini adalah penelitian Aisah. dkk (2020), menjelaskan bahwa terdapat perbedaan perilaku prososial pada anak mendapatkan intervensi dengan digital storytelling (Aisha \& Kaloeti, 2020). Penelitian lain yang mendukung adalah penelitian Sari. dkk (2018), menyatakan adanya peningkatan perilaku prososial anak melalui kegiatan bercerita (Tyas Mustika Sari et al., 2018). Relevansi dengan penelitian ini adalah bahwa empati yang dimiliki oleh anak dasar pengembangan perilaku prososial dan anak usia dini yang memiliki empati tinggi maka mempunyai perilaku prososial yang tinggi pula (Decety \& Cowell, 2014) (Findlay et al., 2006). Sehingga digital storytelling dan bercerita dapat meningkatkan empati anak usia dini. Penelitian selanjutnya yang sesuai dengan hasil dari penelitian ini adalah penelitian Hibbin (2016), mengemukakan bahwa bercerita memberikan manfaat bagi anak antara lain: ekspresi diri, identifikasi dengan karakter cerita, pemahaman mengenai perilaku empati terhadap orang lain, dan komunikasi dua arah (Hibbin, 2016). Hasil penelitian ini bertentangan dengan hasil penelitian Goldstein. dkk (2012), yang mengemukakan bahwa empati anak dapat ditingkatkan secara efektif saat anak melakukan perilaku empati seperti bermain peran (Goldstein et al., 2012). Berdasarkan hasil penelitian tersebut, dijelaskan bahwa empati anak usia akan secara signifikan berkembang bila anak meniru secara langsung empati dari pada hanya mendengarkan melalui cerita.

Untuk mengetahui perbedaan empati anak usia dini yang mendapatkan pembelajaran dengan menggunakan media video animasi dengan anak usia dini yang mendapatkan pembelajaran dengan media big book, maka dilakukan pengujian homogenitas data terlebih dahulu. Pengujian homogenitas ini dilakukan dengan tujuan untuk mengetahui apakah data tersebut homogen atau tidak homogen.

Tabel 4. Hasil Pengujian Homogenitas Data Pretest dan Posttest Group Eksperiment dan Pretest dan Posttest Group Control

\begin{tabular}{ccc}
\hline Levene Statistic & Sig. & Keterangan \\
\hline 4,273 &, 008 & $, 008>0,05$ \\
& & Data dinyatakan homogen
\end{tabular}

Berdasarkan tabel 4 maka terlihat bahwa Sig. yang diperoleh yaitu ,008 dengan Levene Statistic 4,273. Pengujian homogenitas dengan kriteria jika sig $>0,05$, maka data dinyatakan data homogen. Dapat disimpulkan bahwa data pretest dan posttest grup eksperiment serta data pretest dan posttest grup control homogen. Maka untuk mengetahui perbedaan empati usia dini group eksperiment dan group control dilakukan dengan uji Independent Sample T Test.

Terlihat pada tabel 5 nilai Sig (2-tailed) yang diperoleh adalah ,000, jika melihat dari kriteria pengambilan keputusan Sig (2-tailed) $\leq 0,05$, maka dapat diartikan bahwa terdapat perbedaan empati anak usia dini yang mendapatkan pembelajaran dengan media video animasi dengan empati anak usia dini yang mendapatkan pembelajaran dengan media big book. 
Empati Anak Usia Dini: Pengaruh Penggunaan Video Animasi dan Big Book di Taman Kanak-Kanak DOI: $10.31004 /$ obsesi.v6i3.1881

Tabel 5. Hasil Pengujian Independent Sample T Test Data PostTest Group Eksperiment Group Control

Posttest Group Eksperiment Control

\begin{tabular}{cc} 
Sig (2-tailed) & Keterangan \\
\hline, 000 & Terdapat perbedaan
\end{tabular}

Tabel 6. Hasil Pengujian Mean Data PostTest Group Eksperiment Group Control

\begin{tabular}{cc}
\hline Group & Mean \\
\hline Eksperiment & 35,1579 \\
Control & 24,6842 \\
\hline
\end{tabular}

Berdasarkan hasil pengujian mean data posttest group eksperiment dan group control sebagaimana pada tabel 6, maka diketahui bahwa empati anak usia dini yang mendapatkan perlakuan dengan menggunakan media video animasi lebih tinggi bila dibandingkan dengan empati anak usia dini dengan media big book. Teori belajar sosial mengemukakan ketika anak menonton video animasi, mereka akan mengingat karakter dan perilaku tokoh pada video animasi tersebut. Dalam proses meniru perilaku orang lain, anak memperoleh perilaku baru, yang secara bertahap mempengaruhi perkembangan sosial anak pada saat seperti membantu orang lain, berbagi dengan orang lain, dan bekerjasama dengan orang lain. Video animasi dapat membangkitkan ketertarikan anak melalui suara dan gambar, dan membuat anak menjadi senang sehingga membantu mereka untuk berperilaku positif (Liu \& Luo, 2019). Hal ini sesuai oleh hasil penelitian yang dilakukan oleh Bratitsis. dkk (2015) yang mengungkapkan bahwa penggunaan digital storytelling memberikan dampak yang positif tehadap perkembangan empati anak usia dini (Bratitsis \& Ziannas, 2015).

Video animasi adalah salah satu media yang memfasilitasi anak untuk mengetahui situasi yang belum pernah mereka ketahui atau alami sebelumnya, dan membantu untuk meningkatkan kecerdasan emosional anak termasuk empati. Mengingat aspek sosial emosional individu pada usia 3 sampai 5 tahun belum berkembang sepenuhnya, video animasi memungkinkan terbangunnya pemahaman mengenai gagasan yang abstrak sehingga dapat menstimulus aspek sosial emosional anak. Selain itu, bercerita baik secara digital atau menggunakan video maupun tidak atau menggunakan buku telah banyak diteliti, antara lain penelitian yang dilaksanakan oleh Faver. dkk (2012), yang meneliti empati anak usia dini dengan memberikan intervensi cerita hubungan manusia dan hewan (Faver \& Alanis, 2012). Penelitian lain yang mendukung hasil penelitian ini adalah penelitian yang dilakukan oleh Sierksm. dkk (2014), yang meneliti mengenai film pendek dan cerita bergambar sebagai media untuk meningkat kecerdasan emosional yang salah satunya adalah empati (Sierksma et al., 2014).

Pembelajaran inovatif dengan media yang mempuni akan dapat meningkatkan kualitas pembelajaran yang sejalan dengan perkembangan teknologi. Pemanfaatan teknologi informasi pada pembelajaran akan menciptakan pembelajaran yang menarik dan bermakna untuk anak. Video pembelajaran termasuk salah satunya video animasi memiliki kelebihan sehingga banyak dikembangkan dan digunakan dalam pembelajaran terutama pada pembelajaran anak usia dini. Media video animasi pada umumnya mempunyai konten berupa pesan-pesan pembelajaran. Video animasi sebagai media audio visual yang menampulkan gambar animasi dan mempunyai unsur gerak dapat menarik perhatian dan motivasi anak usia dini dalam pembelajaran. Beberapa keunggulan video, antara lain :(1) Video menambah suatu dimensi baru padapembelajaran, video menampilkan gambar bergerak dan suara; (2) Video menayangkan suatu fenomena yang sukar untuk diamati secara langsung (Gusliati et al., 2019). Paparan diatas memperkuat bahwa video animasi lebih efektif untuk meningkat empati anak usia dini bila dibandingkan dengan big book. 


\section{SIMPULAN}

Terdapat perbedaan empati anak usia dini antara kelompok yang mendapatkan intervensi dengan video animasi dan kelompok dengan intervensi menggunakan big bok. Selain itu, disimpulkan juga bahwa empati pada kelompok ekspertimen dengan intervensi menggunakan video animasi lebih tinggi bila dibandingan dengan kelompok kontrol yang medapatkan intervensi menggunakan big book. Hal tersebut dikarenakan video animasi memiliki daya tarik yang lebih besar dibandingkan big book, melalui suara dan gambar bergerak sehingga mudah untuk mengingat dan kemudian meniru perilaku empati yang ditayangkan pada video animasi.

\section{UCAPAN TERIMA KASIH}

Penelitian ini dibiayai penuh oleh hibah penelitian LPPM Universitas Pendidikan Indonesia tahun 2021. Terima kasih kepada TK Tunas Rimba Purwakarta dan TK Plus Roudhoh Purwakarta, yang menjadi tempat pelaksanaan penelitian. Kepada Noviarta, Putri, Sarah, Himah, Sadam, dan Rangga terima kasih telah membatu dalam merancang video animasi empati anak usia dini, big book, dan juga mengumpulkan data penelitian.

\section{DAFTAR PUSTAKA}

Aisha, I., \& Kaloeti, D. V. S. (2020). Digital Storytelling Intervention on Prosocial Behavior Improvement among Early Childhood. Psympathic : Jurnal Ilmiah Psikologi, 7(2), 185196. https://doi.org/10.15575/psy.v7i2.5713

Batson, C. D. (2013). These Things Called Empathy: Eight Related but Distinct Phenomena. The Social Neuroscience of 3-16. https:// doi.org/10.7551/mitpress/9780262012973.003.0002

Decety, J., \& Cowell, J. M. (2014). The complex relation between morality and empathy. Trends in Cognitive Sciences, 18(7), 337-339. https:// doi.org/10.1016/j.tics.2014.04.008

Decety, J., \& Jackson, P. L. (2004). The functional architecture of human empathy. Behavioral and Cognitive Neuroscience Reviews, 3(2), 71-100. https:// doi.org/10.1177/1534582304267187

Dvash, J., \& Shamay-Tsoory, S. G. (2014). Theory of mind and empathy as multidimensional constructs: Neurological foundations. Topics in Language Disorders, 34(4), 282-295. https://doi.org/10.1097/TLD.0000000000000040

Faver, C. A., \& Alanis, E. (2012). Fostering empathy through stories: A pilot program for special needs adoptive families. Children and Youth Services Review, 34(4), 660-665. https:// doi.org/10.1016/j.childyouth.2011.12.012

Findlay, L. C., Girardi, A., \& Coplan, R. J. (2006). Links between empathy, social behavior, and social understanding in early childhood. Early Childhood Research Quarterly, 21(3), 347-359. https://doi.org/10.1016/j.ecresq.2006.07.009

Gehlbach, H. (2004). Social perspective taking: A facilitating aptitude for conflict resolution, historical empathy, and social studies achievement. Theory and Research in Social Education, 32(1), 39-55. https://doi.org/10.1080/00933104.2004.10473242

Goldstein, T. R., College, B., \& Zero, H. P. (2012). Enhancing Empathy and Theory of Mind Ellen Winner. https:// doi.org/10.1080/15248372.2011.573514

Gusliati, P., Eliza, D., \& Hartati, S. (2019). Analisis Video Pembelajaran Share Book Reading Menggunakan Cerita Rakyat Sabai Nan Aluih pada Anak Usia Dini. Jurnal Obsesi : Jurnal Pendidikan Anak Usia Dini, 3(2), 320. https:// doi.org/10.31004/obsesi.v3i2.176

Hana Pebriana, P. (2017). Analisis Kemampuan Berbahasa dan Penanaman Moral pada Anak Usia Dini melalui Metode Mendongeng. Jurnal Obsesi : Jurnal Pendidikan Anak Usia Dini, 1(2), 139-147. https:// doi.org/10.31004/obsesi.v1i2.34 
Empati Anak Usia Dini: Pengaruh Penggunaan Video Animasi dan Big Book di Taman Kanak-Kanak DOI: $10.31004 /$ obsesi.v6i3.1881

Hibbin, R. (2016). The psychosocial benefits of oral storytelling in school: developing identity and empathy through narrative. Pastoral Care in Education, 34(4), 218-231. https:// doi.org/10.1080/02643944.2016.1225315

Hoffman, M. L. (2019). The Contribution of Empathy to Justice and Moral Judgment. In Readings in Philosophy and Cognitive Science. Cambridge University Press. https://doi.org/10.7551/mitpress/5782.003.0038

Hoffman, Martin L. (2000). Empathy and Moral Development. In Empathy and Moral Development. Cambridge University Press. https://doi.org/10.1017/CBO9780511805851

Latif, M., Zukhairina, Zubaidah, R., \& Afandi, M. (2016). Orientasi Pendidikan Anak Usia Dini Teori dan Aplikasi. Prenada Media Group.

Liu, Q., \& Luo, W. (2019). the Influence of Animation on the Social Development of Preschool Children. Educational Innovations and Applications, 135-138. https://doi.org/10.35745/ecei2019v2.035

Mardliyah, S., Yulianingsih, W., \& Putri, L. S. R. (2020). Sekolah Keluarga: Menciptakan Lingkungan Sosial untuk Membangun Empati dan Kreativitas Anak Usia Dini. Jurnal Obsesi: Jurnal Pendidikan Anak Usia Dini, 5(1), 576-590. https://doi.org/10.31004/obsesi.v5i1.665

Mark H. Davis. (1983). Measuring Individual Differences in Empathy: Evidence for a Multidimensional Approach. Journal of Personality and Social Psychology , 113-126. https://doi.org/10.1037/0022-3514.44.1.113

Mcdonald, N. M., \& Messinger, D. S. (2013). The Development of Empathy: How, When and Why. Free Will, Emotions, and Moral Actions: Philosophy and Neuroscience in Dialogue, 1-36.

Mega Purnamasari, Y., Wuryandani, W., Kunci, K., \& Aly Syukron Aziz Al Mubarok, A. (2019). Media Pembelajaran Big Book Berbasis Cerita Rakyat untuk Meningkatkan Karakter Toleransi pada Anak Usia Dini. Jurnal Obsesi : Jurnal Pendidikan Anak Usia Dini, 4(1), 90-99. https:// doi.org/10.31004/obsesi.v4i1.273

Sierksma, J., Thijs, J., \& Verkuyten, M. (2014). Children's intergroup helping: The role of empathy and peer group norms. Journal of Experimental Child Psychology, 126, 369383. https:// doi.org/10.1016/j.jecp.2014.06.002

Tyas Mustika Sari, I., Toha, H., \& Nurani, Y. (2018). Improving Early Childhood Prosocial Behavior through Activity Storytelling with Puppets. Jurnal Obsesi : Jurnal Pendidikan Anak Usia Dini, 2(2), 155-161. https://doi.org/10.31004/obsesi.v2i2.75

Vachon, D. D., Lynam, D. R., \& Johnson, J. A. (2014). The (Non)relation between empathy and aggression: Surprising results from a meta-analysis. Psychological Bulletin, 140(3), 751773. https:// doi.org/10.1037/a0035236

Van Lange, P. A. M. (2008). Does Empathy Trigger Only Altruistic Motivation? How About Selflessness or Justice? Emotion, 8(6), 766-774. https:// doi.org/10.1037/a0013967

Williams, E., Berard, A., \& Barchard, A. (2005). Distinguishing between Three Different Aspects of Empathy. Journal of Personality, 4, 2-3. 